Canadian University Music Review

Canadian University Music Review

Revue de musique des universités canadiennes

\title{
Istvan Anhalt. Alternative Voices: Essays on Contemporary \\ Vocal and Choral Composition. Toronto: University of Toronto \\ Press, 1984, xi, 336 pp.
}

\section{David Piper}

Numéro 5, 1984

URI : https://id.erudit.org/iderudit/1014014ar

DOI : https://doi.org/10.7202/1014014ar

Aller au sommaire du numéro

Éditeur(s)

Canadian University Music Society / Société de musique des universités canadiennes

ISSN

0710-0353 (imprimé)

2291-2436 (numérique)

Découvrir la revue

Citer ce compte rendu

Piper, D. (1984). Compte rendu de [Istvan Anhalt. Alternative Voices: Essays on Contemporary Vocal and Choral Composition. Toronto: University of Toronto Press, 1984, xi, 336 pp.] Canadian University Music Review / Revue de musique des universités canadiennes, (5), 325-330. https://doi.org/10.7202/1014014ar

All Rights Reserved (C Canadian University Music Society / Société de musique des universités canadiennes, 1984
Ce document est protégé par la loi sur le droit d'auteur. L'utilisation des services d'Érudit (y compris la reproduction) est assujettie à sa politique d'utilisation que vous pouvez consulter en ligne.

https://apropos.erudit.org/fr/usagers/politique-dutilisation/ 
in the Lord by T. Turvey, an idiosyncratic modulation as in J.P. Clarke's Trisagion (mm. 41-44), or downright crudity as in the chain of seconds (or ninths if the middle voice is performed by a tenor) in the fourth measure of Humbert's Hail to the Day Spring. The selections from Bish op John Medley's Church Anthems, Services and Chants which end the volume are the only Protestant works that approach the level of technique and imagination shown in the contemporaneous Roman Catholic sacred music.

It remains to be seen whether this and other publications of the Canadian Musical Heritage Series will create any widespread interest in Canada's musical past. At the very least the series will make a selection of early musical Canadiana available to a wider public. Moreover, it will provide a much-needed companion to the several monographs on early Canadian music and doubtless provide the raw material for future ones. Finally, whatever the intrinsic or relative merits of the music presented in this and future collections, it yields a valuable insight into over two centuries of domestic musical activity in Canada.

Robin Elliott

\section{REFERENCE}

AMTMANN, W.

1975: Music in Canada 1600-1800. Montreal: Habitex Books.

Istvan AnHalt. Alternative Voices: Essays on Contemporary Vocal and Choral Composition. Toronto: University of Toronto Press, 1984, xi, $336 \mathrm{pp}$.

In attempting to develop analytical tools and interpretative modes of expression necessary for the clear verbal articulation of ideas essentially musical in their manner of formulation and presentation one is faced with an early and inescapable dilemma. Essentially the problem, which addresses the fundamental and perpetual question of exactly what music expresses, reduces to a simple choice.

On the one hand it is possible to treat music as a self-referential system of concrete techniques and symbols whose power and significance as elements in an artistic statement are measured and explained solely in the extent of their mutual interaction and nurturing and in the degree to which they combine to realize that statement. Such an approach has had a long and useful history. After all, the techniques of performance and composition have to be learned and applied, and the necessity of this will, it is hoped, continue to be evident.

On the other hand, the fact has to be recognised that this approach is incapable of tackling the more generally important questions which 
arise from consideration of music in its actual socio-historical context. Music thus interpreted (that is, music considered as the heightened expression of an individual or group insight into contemporary reality) is a social act in the important sense that it carries significance for the listener and participant only to the extent that its socio-historical context of origin is both acknowledged and understood. It is evident that the defining of the particular socio-historical context, and the interpretation of music as an articulation of insights arising from that context, demands intellectual tools quite different from those necessary for the interpretation of music considered as a self-referential system. Indeed, such interpretation demands special insights of its own whose nature and quality derive from an essentially inter-disciplinary mode of analysis. One suspects it is this latter formidable demand that accounts for the apparent lack of a solid, rigorous, and satisfying contemporary tradition of musical analysis, a developed body of intellectual techniques capable of interpreting in an articulate and convincing manner the work of present-day composers as both significant contemporary intellectual and spiritual insight and as social metaphor.

The problem of meaningful interpretation becomes particularly acute when faced with the more advanced vocal literature of our time. The human voice, more directly and far more intimately than instrumental music, is an utterance of the soul. Much of the more extreme vocal expressions of contemporary music, comprising an enormous range of buccal and respiratory noises, as well as vocal sounds of enormous pitch range and rapidity of change, inarticulate cries, screams, gasps, and sighs, produce an affect, sometimes brutal and anguished, sometimes hilarious, but always disturbing in their musical context. The laying bare of a human soul in such an extreme manner may sometimes, indeed, induce in the listener a feeling akin to personal violation. Such music is not comfortable. But it will not go away, and it demands a response. Because so much of this vocal literature, due to the very nature of its utterances, reaches out to areas of experience quite outside the purely musical (and for the sake of argument we must assume that such a purely musical area actually exists) an appropriate response can only be formulated upon an understanding that an interdisciplinary analytical and interpretative approach provides.

Istvan Anhalt's Alternative Voices is an important and timely publication. A path-breaking book, it is the first major study which attempts to apply consistently, and in depth, an inter-disciplinary approach to the interpretation of this literature.

On first perusal the book may strike one as perhaps a little too much to handle. The degree of erudition displayed is certainly impressive, and the amount of sheer information is staggering for a text only slightly in excess of 300 pages. To turn to the bibliography is a daunting experience, and, to be honest, one's initial reaction is to assume, somewhat sceptically, that much of it is academic padding; 
however, a closer inspection reveals that the over 400 listed items are indeed genuine sources, at least $50 \%$ of which are actually cited in the text.

The book has had a long gestation period; we learn that the earliest portions reached their present form as long ago as 1972. The analytical techniques, novel as they may be to many readers, are handled with the assurance that their long and, one assumes, habitual application develops. Anhalt is an honest writer. The text does not pass over analytical difficulties or possible inconsistencies. Although such instances are not numerous (in fact, remarkably few for a study of such breadth and novelty of approach), Anhalt helpfully places them before the reader, usually with a tentative, qualified interpretation, and in so doing serves, paradoxically, to inspire confidence in the essential overall soundness of his approach.

The study is organized into two main parts, prefaced by an introductory historical essay. The latter, which defines the theme and provides a historical context for the contemporary literature, is itself a minor encyclopedic document, delving into the traditions of melodrama and the practitioners of recitation and declamation, choral recitation, Dada and Futurism, sound poetry, as well as into the more direct musical antecedents to be found in works such as Schoenberg's Pierrot Lunaire.

The core of the study is the material of Part I, three chapters that deal with the analysis and interpretation of three major works of modern vocal literature: Berio's Sequenza III (1966), Ligeti's Nouvelles Aventures (1965) and Lutoslawski's Trois Poèmes d'Henri Michaux (1963).

While these chapters do contain analytical and descriptive comments of a purely technical nature (e.g., the twelve-note permutational system that underlies parts of Nouvelles Aventures, and the various types of mass-structure employed by Lutoslawski) the main approach is a socio-linguistic one, with occasional important and imaginative interpretations derived from the disciplines of psychology and psychotherapy, psychiatry, phonetics, anthropology, and literary criticism. What is revealed is an utterly fascinating and convincing interpretation of what this music is "about" and why it takes the form that it does. Most importantly, the study reveals this music to be very much a part of the mainstream of contemporary consciousness. It displays an exciting unity of perception, albeit differently articulated, between contemporary disciplines.

The chapters on Berio and Ligeti are entirely convincing and satisfying in the manner and to the extent that the linguistic and sociopsychological disciplines are brought to bear upon the music. The result is a welcome re-shaping of one's attitude to these problematic works through the acquiring of a fresh understanding of their purpose and nature. The chapter dealing with Lutoslawski's Trois Poèmes 
d'Henri Michaux is, by contrast, a trifle disappointing in that the connections between the concrete musical material and the text, the nature of the text and its relation to the style and techniques of the setting, are not clearly revealed. For instance, there is careful description of the various types of vocal and instrumental mass-structure, but apart from an introductory implication of mass-structure as a metaphor of the social collective, there is little convincing interpretation (as distinct from description) of the different types. The parts of this chapter do not seem to come together to form quite as convincing a whole as do the parts of the other two chapters.

Part II comprises four essays which deal with more general themes arising from the consideration of the new vocal literature. Again Anhalt draws on other disciplines in order to illuminate certain common situations: speech pathology, vocal physiology and semiotics; ethnomusicology; Asian religious writings, practices, and philosophies; magic chant and ritual - the range is enormous.

The first essay, "Blurred Bounderies," is largely an exposition of the inescapable inter-disciplinary reality confronting us, and an argument for the necessity of re-evaluating traditional definitions and practices within the musical discipline itself. "Deep Themes, Not So Hidden" is in search of memories: racial, cultural, childhood. The awesome potency of proper names, of repetitive spoken and chant formulas, of mystical and arcane patterns of words and syllables for shaping, directing, and revealing the forces and secrets of the intertwined spiritual and material universes modern homo rationalis scorns, for ultimately his arid intellectual and rigidly circumscribed world of reasoned experience cannot but exclude the ineffable. But it is precisely these vital passions of earlier homo spiritualis which so many of the texts, styles, and settings of contemporary vocal literature attempt to rekindle. In so reaching into the "pit of time," in grasping at what Anhalt, citing Gerald Bruns, calls "the moment before speech," music explores and utilizes the vast repertoire of acoustic material emanating from differentiated and controlled "vocal-tract behaviour" (Anhalt's phrase). "Orpheus Resurgent ... Perhaps" deals with this aspect of contemporary vocal repertoire in an essay which, for its sheer amount of information alone, ought to become required reading for every student composer. Part II concludes with "Alternative Voices," an examination of three more works illustrative of the themes running deep through the book: John Beckwith's Gas!, R. Murray Schafer's In Search of Zoroaster, and Luciano Berio's Coro.

In the face of such an important publication and of the intellectual tour de force it represents, it would appear somewhat querulous to offer criticism. But there are problems.

What will immediately strike the reader are the obscurities of language that result from the constant confrontation with jargon terms and phrases. Of course, each discipline has its store of specialized 
terms, and from its inception this study was, by its very nature, bound to be bedevilled by the conflicting styles and semantics of its component disciplines. Anhalt, in aiming the book at a readership probably more attuned to the jargon of musicology and music theory has done well to reduce the degree of non-musical jargon to a low level. Occasionally, however, the need to interpret or re-phrase specialist terms is forgotten. In reference to the text of Sequenza III we read that "its type/ token ratio is $19 / 23$ " (p. 34); on the following page the term "semanticdifferential rating" is employed. In neither case is the reader directly helped in dealing with these linguistic and perceptual obstacles, both of which, it would seem, are important in the argument. It is true that for each term a bibliographic reference is provided, but for anybody except the person who confines reading activity to the inside of a university general reference library a reasonably succinct footnote definition would have been of inestimable greater immediate help. Other terms include "kinesics" (a common, yet undefined, concept in Chapter 3) and "phatic communion" from the same chapter (to which bibliographic reference is made but which receives no further attempt at elucidation). By contrast, and somewhat inconsistently in this pattern, the term "syntality" does receive a helpful footnote definition (with additional bibliographic reference). In short, it does not seem unreasonable to suggest that in a first inter-disciplinary study of this complexity and depth the reader is entitled to all the help that can be provided.

The attempt to classify and to discover patterns is an essential component of Anhalt's analytical approach. Up to a point it is an invaluable intellectual tool capable of revealing an enormous amount of potentially useful information for subsequent interpretation. But the process does make for tedious reading, and can get a little out of hand: the fetish of systematizing may sometimes obscure the obvious. The affective sequence comprising Scene 5 of Nouvelles Aventures (mm. 30-39) is subjected to a rigorous and laudable attempt at the classification of elements, and does indeed result in the revealing of underlying patterns. As a description of musical choices and processes employed by Ligeti it is undeniably interesting and informative, but as an interpretation of the music itself it is still-born. Anhalt himself seems to recognize this, for he immediately approaches the passage again from an altered analytical perspective; as he says: "A less systematic analysis may take a simple descriptive shape" (p. 67). What follows are three short paragraphs of subjective interpretation based on Anhalt's own insights informed by psycho-linguistics. The interpretation is immediately meaningful and the music comes to life. It is a striking confirmation of Ligeti's own claim that the music is "a conceptualization of relationships between affective modes of comportments, not an abstract structural plan" (p. 91).

The propensity toward abstraction and complexity may obscure, 
rather than throw light on, a passage under scrutiny. An orchestral section from Lutoslawski's Trois Poèmes d'Henri Michaux is categorized as "a constantly poly-metric, periodically single-phase construct using the divisions $1 / 2,3 / 4,5 / 8^{\prime \prime}$ (p. 139). Here the terrifying and grotesque linguistic specters of Die Reihe and Perspectives of New Music may begin to materialize, only to be confirmed in their immanence by a resort to time measurements which are used to demonstrate "the palindromically symmetrical pattern of attack distances..." (ibid.) and "the complexity of the varying time distances between the attacks..." (ibid.). Now this is using a jack-hammer to crack an almond. The simple fact is that Lutoslawski, in order to create a mass-sound, has resorted to an old trick, beloved of Stockhausen, of combining in simultaneity rhythms that have a harmonic and equal phase relationship with each other; we have, in this case, an incomplete harmonic rhythmic spectrum containing partials $2,3,4,5$, and 8 . Understood in this light the palindromic construction of note attacks within the beat results quite naturally from the harmonic division of that beat, and no misleading significance need be implied by that pattern. This still does not, of course, tell us why such a procedure was employed, but at least it does not suggest a complexity of technique that is clearly at odds with the reality. It may also help to avoid an inexplicable error of observation where it is stated, in a following sentence to those cited above, that "the 500-millisecond durations are not [stress Anhalt's] employed to mark the beginning of, and the half-way point between, the beats..." (pp. 139-40). A perusal of the passage in question reveals that these "500millisecond durations" do, indeed, mark off the half-way points (see cl. II, tbn. I, in Ex. 4.10 p. 119). Anhalt's description of this passage as non-periodic (p. 140) is also puzzling.

One other error which ought to be mentioned is the misspelling of Werner Meyer-Eppler (not Mayer-Eppler). This appears both on page 106 and, more importantly, in the index (p. 325).

Alternative Voices is by no means an easy book to read and digest. In its tone of language and in its concern with detail and bibliographic substantiation it is not unrelated to that most indigestible of literary forms: the doctoral thesis. But perseverence certainly brings rich rewards. It is the sort of book that can turn one's mind to contemplate things (not just music) from a totally fresh perspective. Despite some infelicities of style it is to be welcomed as a very significant and muchneeded scholarly work in this area.

David Piper

R. MurRay SCHAFER. R. Murray Schafer On Canadian Music. Bancroft: Arcana Editions, 1984, x, 105 pp.

Here in one slim volume is a baker's dozen of articles on Canadian 